\title{
Joanna SKUBISZ
}

ORCID: 0000-0001-7494-9962

Uniwersytet Wrocławski

\section{De wonderlijke boekenwereld in het Nationaal Museum van Wrocław}

In mei - juli 2018 organiseerde het Nationaal Museum van Wrocław in Polen een tentoonstelling van de oude drukken uit de collectie van zijn bibliotheek. Naar aanleiding daarvan hebben twee curatrices: Barbara Fercowicz en Maria Piotrowska een catalogus opgesteld, getiteld Sztuka druku (De drukkunst).

Het boek bestaat uit drie 'gedeelten': de inleiding van M. Piotrowska, de catalogus van de tentoongestelde drukken en drie registers: Index van afkortingen en namen van instellingen, Literatuurlijst en Index van drukkers, uitgevers en auteurs. Er werden eveneens vijfenveertig reproducties van enige drukkers- en uitgeversmerken geplaatst.

In de inleiding van Piotrowska werden o.m. de lotgevallen van de museumbibliotheek gepresenteerd. Men vindt hier gegevens over oude bibliotheken waarvan drukken tegenwoordig tot de collectie van het Wrocławse museum behoren: zgn. Bibliotheca Milichiana uit Görlitz, Die Lehrerbibliothek des Königlichen Gymnasiums zu Brieg e.a. In het laatste hoofdstuk van de inleiding presenteert Piotrowska de boekgeschiedenis vanaf het begin van de drukkunst in de 15 de eeuw via de ontwikkeling daarvan tussen de 16de en de 18de eeuw. De auteur beschrijft de situatie in verschillende landen: Duitsland, Italië, Frankrijk, Nederland, Spanje, België, Engeland, Polen e.a.

Tekstfragmenten over Nederland en België bevatten volgens mij enkele inconsequenties. M. Piotrowska vertelt over "de steden van de Nederlanden" (miasta Niderlandów) waar de boekdrukkunst zich ontwikkelde en ze noemt op: Utrecht, Brussel, Delft, Antwerpen en Haarlem. Op een andere plaats - na Spaanse en Portugese uitgeverijen gepresenteerd te hebben - heeft ze het over de situatie in "het Belgische Brugge". Het is hier belangrijk op te merken dat er in de 16de en $17 \mathrm{de}$ eeuw een dergelijke staat als België niet bestond. Piotrowska gebruikt huidige landnamen en ze vermeldt Nederland (in het Pools: Holandia) en België apart maar ze is mijns inziens niet consequent. Ze kwalificeert namelijk Brussel en Antwerpen als Nederlandse steden maar Brugge als een Belgische stad. Voorts werden als eerste Nederlandse drukkers Laurens Janszoon Coster (1370-1440?) en Johann von Paderborn (1450-1501) genoemd. Von Paderborn werkte in Aalst en Leuven maar in de inleiding staat de eerste stadsnaam verkeerd als "Alost" opgeschreven en de tweede stad - Leuven - wordt helaas helemaal niet vermeld. Het gebrek aan deze informatie kan verbazing wekken. Verder concentreert de auteur zich alleen op de activiteiten van de drukkersfamilie Elzevier hoewel men in de catalogus ook drukken van Plantin, Blaeu en andere Nederlandse editeurs kan vinden. Tot slot geeft de curatrice een professionele uitleg over oude boekformaten. 
In de catalogus zelf zijn er 125 oude drukken beschreven die op de bovenvermelde tentoonstelling werden gepresenteerd. Ze zijn geografisch gerangschikt op de landen en steden van de uitgave. Eerst stelt men boeken voor die in Duitsland - het geboorteland van de drukkunst - zijn verschenen. De volgende landen en steden zijn alfabetisch geordend. De situering van de steden is vastgesteld op basis van de tegenwoordige verdeling van grenzen. Elke druk wordt volgens één model gepresenteerd: trefwoord, drukker, uitgever, omvang van het boek (met alle cijfers en afmetingen: het aantal folia, het formaat etc.), beschrijving van het incipit en colofon (voor incunabelen), omslag (het materiaal, de versieringen, soms beschadigingen), druktype, provenançegegevens (letterlijk uit het boek overgenomen), signatuur van de museumbibliotheek, inhoud van het boek en geraadpleegde literatuur. In het trefwoord zijn ook de gestandaardiseerde auteursnaam opgenomen, de titel van het werk of diens begin en het jaar van de uitgave. Verder worden genoemd: de belangrijkste gegevens van de auteur, vertaler en personen aan wie het werk werd opgedragen. Daarna zijn de drukkers- of uitgeversmerken, het frontispice en de illustraties geanalyseerd.

De catalogus van Fercowicz en Piotrowska toont zeker een interessante collectie van de oude drukken in het bezit van het Nationaal Museum van Wrocław, waaronder: Cosmographia van Peter Apian - Duitse mathematicus, cartograaf en astronoom (ed. Antwerpen 1545), een encyclopedisch werk Onomasticon en vivliois deka... van Julius Pollux (ed. Amsterdam 1706; de titel staat in de catalogus deels foutief gedrukt: in plaats van vivliois zou er bibliois moeten staan) of Notce \& castigationes in Stephanum Byzantium De urbibus - een aardrijkskundig werk van Lukas Holstein (foutief in de catalogus genaamd als Holste), verschenen in 1692 te Leiden. Wat opvalt, zijn meerdere Bijbel-uitgaven voorzien van prachtige houtsneden of gravures bijv. Biblia latina (Vulgaat) gepubliceerd in 1480 te Nürnberg. De technische omchrijving (omslag, formaat, grootte, druktype) en inhoudelijke gegevens (de thematiek van het boek alsook zijn historische, religieuze en maatschappelijke context) zijn nauwkeurig en betrouwbaar. Vermeldenswaard is een rijk fotografisch materiaal. Enkele twijfels kan de geografische verdeling van de uitgaveplaatsen wekken. De criteria van deze verdeling lijken mij deels vaag. Het is begrijpelijk om de uitgaveplaatsen binnen de tegenwoordige staatsgrenzen te plaatsen, vooral vanwege hun vaak ingewikkelde verleden. Historisch gezien is dit echter niet helemaal juist. In geval van drukken die in de 16de en 17de eeuw in de Nederlanden verschenen, worden België en Nederland apart vermeld hoewel er toen nog geen België bestond. De onafhankelijkheid daarvan werd pas in 1830, na de Belgische Revolutie uitgeroepen. Naar mijn mening zou het overzichtelijker kunnen zijn over de Noordelijke en Zuidelijke Nederlanden te schrijven met een extra uitleg: het tegenwoordige Nederland of België. Een kleine verwarring bestaat ook in het geval van Duitsland en Polen en specifiek Silezië. Silezische steden als Brzeg (Brieg), Jawor (Jauer), Jelenia Góra (Hirschberg) Kłodzko (Glatz), Legnica (Liegnitz) of Wrocław (Breslau) waren geen Poolse steden in de 16de en de 17de eeuw maar hoorden bij het Habsburgse Rijk. In de 18de eeuw is Silezië het bezit van het Koninkrijk Pruisen geworden. Problematisch is ook de kwestie van Zgorzelec/Görlitz. Onder boeken uitgegeven in Duitsland, vindt men namelijk één werk gepubliceerd in "Zgorzelec". Tot 1945 bestond er geen Poolse stad Zgorzelec maar uitsluitend Duits Görlitz. Na deze datum werd de stad in het Poolse en Duitse gedeelte verdeeld. Echter, in de periode tussen de $16 \mathrm{de}$ en de $17 \mathrm{de}$ eeuw bevonden zich alle drukkerijen in het tegenwoordig Duitse stadsdeel, dus in Görlitz, zoals in geval van de zaak van Ambrosius Fritsch die het boek, opgenomen in de catalogus, heeft gedrukt. Piotrowska legt in de inleiding uit dat de auteurs van de catalogus Poolse namen van steden hebben gebruikt. Naar mijn mening kan het Poolse Zgorzelec in plaats van het Duitse Görlitz in dit geval misleidend zijn. Niet iedereen leest de inleiding zo nauwkeurig of kent de geschiedenis van de regio. Het grootste nadeel vind ik echter het gebrek aan uitgebreide gegevens van de eigenaars die de beschreven drukken in hun bezit hadden en van wie namen in de provenançes werden vermeld. Deze gegevens vergroten onze kennis over de lotgevallen van de verzameling en tonen de historisch-maatschappelijke context van de collectie: hoe kwamen deze boeken naar Silezië, wie heeft ze gekocht, gelezen en om welke redenen? Misschien zal deze kwestie in een aparte publicatie worden onderzocht. 
Samenvattend vind ik de catalogus Sztuka Druku een geslaagde publicatie die duidelijk aantoont dat er in Silezië belangstelling bestond voor de Europese boekdrukkunst. Bovendien bewijst hij ook dat de bibliotheek van het Nationaal Museum in Wrocław over een indrukwekkende collectie oude drukken beschikt die relevant materiaal voor verder onderzoek biedt.

Barbara Fercowicz, Maria Piotrowska, Sztuka druku. Europejskie oficyny wydawnicze w starodrukach Biblioteki Muzeum Narodowego we Wrocławiu. Katalog wystawy, Wrocław: Muzeum Narodowe we Wrocławiu, 2018, ISBN 978-83-65563-47-7, 100 pp. 